\title{
Legal Security Differences: Co-operative Comparison Between The United Kingdom And The Netherlands
}

\author{
Damy W. Colon \\ Faculty of Economics and Business/ University of Groningen, the Netherlands; \\ PricewaterhouseCoopers Europe.
}

\begin{abstract}
This paper explores the co-operative compliance approaches implemented by the UK and the Netherlands. The commonly applied legal co-operative compliance framework is used to compare both countries. Both the UK and Dutch approach on co-operative compliance are analyzed with the framework. It is concluded that the UK co-operative compliance approach creates legal security. The Dutch co-operative compliance approach is not creating legal security. These findings are elaborated considering common and civil law. Moreover, the differences in co-operative compliance are discussed in an international context. It is concluded, that from an international perspective the UK co-operative compliance approach is desirable as long as other countries follow the Dutch co-operative compliance approach.
\end{abstract}

Keywords: co-operative compliance, tax law, common law, code law, United Kingdom, the Netherlands, transfer pricing, tax administrations, HMRC, corporate governance, tax controlling, tax economics.

\section{INTRODUCTION}

The OECD's co-operative compliance initiative is implemented by many countries worldwide. In the scientific literature the research on co-operative compliance is limited [1] [2]. The available co-operative compliance literature is focused on a framework for comparing cooperative compliance approaches. The current state of the legal co-operative compliance framework [3] [4] is applied to compare the United Kingdom and the Netherlands. This scientific research is the first comparing co-operative compliance approaches between countries.

\section{CO-OPERATIVE COMPLIANCE FRAMEWORK}

In this section the UK and Dutch co-operative compliance regimes are compared. This comparison is based on the common legal co-operative compliance framework. The framework is as follows [5] [6]:

- Companies have clarity about how to comply with co-operative compliance (Clarity);

- Looking forward and real-time action to ensure that tax uncertainties are prevented or detected when they occur (timely);

- Put effort on the operations related to taxes (non-tax);

- Make it easy to comply and hard to not comply with laws and regulations (enforcement);

- Involve actively the tax payers, their representatives and other stakeholders with the purpose of better understanding and cooperation between parties (involvement).

After the analysis of the framework a conclusion is drawn on the comparison of both co- 
operative compliance regimes.

Clarity. The UK co-operative compliance regime has a high level of clarity. The Dutch cooperative compliance regime has a low level of clarity. Based on clarity the UK and Netherlands has implemented opposite regimes. Both countries are at the different end of the clarity spectrum. The UK has guided as much as possible and documented even examples how to apply for low risk. The Netherlands has guided as less as possible not even stating the requirements to apply for low risk. Both regimes have their own advantage and disadvantage. The UK regime relies on structure/ clarity and is therefore less flexible. The Dutch regime relies on flexibility and is therefore less structured/ clear.

Timely. The UK co-operative compliance regime has no safeguarding for timely responses on uncertain tax positions. This stems from the perception that low risk companies can make sufficient professional judgements. This is opposed to the Netherlands. The Dutch regime relies on timely responses as it is assumed that every uncertain tax position is to be discussed with the tax administration.

Non-tax. Both the UK and Dutch co-operative compliance regimes has an inherent focus on including non-tax processes.

Enforcement. The UK co-operative compliance regime is applying the enforcement model the OECD mentions: stimulating enforcement by law and benefits for complying with the law. Companies should voluntary apply for co-operative compliance. The enforcement of the OECD was not implied as enforcing companies into co-operative compliance. This is what the Netherlands is doing. The Netherlands enforces companies to participate in co-operative compliance without stimulating companies with benefits.

Involvement. Both the UK and the Netherlands allow all stakeholders to make comments on the co-operative compliance regime.

Overall. The differences between the UK and Dutch co-operative compliance regime stems from the analysis of five specific principles. Thoroughly different approaches have been applied for co-operative compliance. The approaches of the UK and the Netherlands appear to be opposites of each other. The UK has an abundant level of guidance. The Netherlands has a lack of guidance. The UK aims to document as many possible outcomes, behaviour and responsibilities before the tax activities occur. The Netherlands aim to act real-time with professional judgement and a high level of flexibility for both the taxpayer and the tax administration. Where the Netherlands called the co-operative compliance variant "horizontal monitoring", the UK is actually operating horizontal. The Netherlands is actually operating with vertical relationships. The taxpayers must commit to the professional judgement and approach of the tax administration (or start legal proceedings). This difference in approach is also evident in the enforcement by the tax administrations. The HMRC stimulates the use of the cooperative compliance approach. The Netherlands forces companies into co-operative compliance. The UK and the Netherlands implemented different variant of co-operative compliance, even though both approaches were initiated by the OECD.

\section{LEGAL SECURITY}

On the first sight it appears that the UK co-operative compliance approach is creating more legal security for taxpayers than the Dutch co-operative compliance approach. The UK approach has guidance on many aspects and the decision process of the tax administration is 
transparent. The Dutch co-operative compliance approach is unguided creating uncertainty. To understand the differences and/ or similarities the general legal perspective of both countries is elaborated. In this general legal perspective the legal security of the co-operative compliance approaches is analysed.

\section{United Kingdom}

In the United Kingdom common law is applicable [7]. Common law is a system where judicial precedent applies, judicial decisions are binding and are used to develop the law [8] [9]. This approach of law is to a large extent based on tradition. Key stone cases are important in legal proceedings. The legal environment is comparable with the legal environment of the United States. Companies aim to cover as many aspect as possible in contracting as turning to court can be expensive and the outcome is less evident than that of an exhaustive contract. In the circumstance of disagreement the method for resolving the disagreement is described in these exhaustive contracts. Legal security is in the basis derived from exhaustive contracting.

From the common law perspective the UK co-operative compliance approach is better understood. As it is common to formulate clear expectations and rules in a business relation, the HMRC fit the co-operative compliance regime in the legal environment of the UK. Companies are used to have stringent agreements before entering in a business relation. With the current structure of co-operative compliance the business relation between companies and HMRC is well defined and consists of many uncertainties. The approach for co-operative compliance is therefore creating legal security for companies participating in co-operative compliance. If disagreements occur conflicting parties can point to the general tax compliance framework and stems security from this framework.

\section{The Netherlands}

In the Netherlands civil law is applicable [10] [11]. Laws are based on the decisions of policy makers. Jurisprudence can stimulate changes in law only as there is no law on a specific aspect. Once there are new laws the jurisprudence on a specific topic becomes useless. The creation of law is not necessarily in accordance with jurisprudence. In Dutch law the law practitioners are allowed a high level of professional judgement. The Dutch court is allowed to interact in the legal proceedings by requesting information not put forward by conflicting parties. Of course, this professional judgement is allowed with the assumption that the court is unprejudiced. If a conflicting party assumes prejudice, the party can ask for replacement of the judges. An independent commission decided on replacement. In tax law the high level of professional judgement is also applicable. Tax inspectors are allowed to make professional judgement on tax positions. If a taxpayer disagrees with the tax administration's decision the court concludes on the reasonableness of the decision.

The legal environment in the Netherlands is evident in the Dutch co-operative compliance approach. In the Netherlands co-operative compliance is mainly unguided. Companies are allowed to apply their own professional judgement on the design of a TCF. The tax administration/ tax inspector can make its own professional judgement on the design of a TCF and the consequent reporting requirements for the company. Co-operative compliance seems not to create legal security. However, as co-operative compliance is unguided, disagreements results in the general legal proceedings. Disagreement of tax positions between the taxpayer and tax administration result in legal proceedings comparable with the situation without cooperative compliance. No clear guidelines from the tax authorities results in no change in the legal environment. The Dutch co-operative compliance approach is itself not creating legal security. 


\section{Comparing the UK and Netherlands}

Putting the UK and the Netherlands in their own legal environment created new insight on their co-operative compliance approaches. The Dutch variant of co-operative compliance is in accordance with the high level of professional judgement. However, it seems that there is no legal security aimed with the co-operative compliance approach. On the opposite, the UK variant seems to create legal security. The UK co-operative compliance approach is in accordance with the UK legal environment. Moreover, the accordance with the legal environment is creating security for participants. The framework for compliance is created, published and clear. Companies are aware of the expected behaviour and are therefore able to act accordingly. The Dutch co-operative compliance regime is considered on the broader legal environment and is therefore not creating changes in the legal environment. For legal proceedings the former legal framework is still applicable.

\section{DISCUSSION}

In this research the UK and Dutch co-operative compliance approach are compared. The goal of the research was to conclude on the legal security created by both approaches. From the different chapters it became evident that the UK and the Netherlands has interpreted the OECD in their own legal perspective. The UK implemented co-operative compliance with as many as possible legal guidance where professional judgement is limited. The Netherlands implemented co-operative compliance with as less a possible guidance giving companies the possibility for their own professional judgement on creating a TCF. The UK and Dutch cooperative compliance approach are opposites of each other.

In this research five OECD principles are considered for concluding on the differences: clarity, timely, non-tax, enforcement and involvement. These principles created insight in the opposites applied by the United Kingdom and the Netherlands. From the difference in law system the approaches were explainable.

With regards of legal security there are also differences. The UK has created a legal framework for co-operative compliance including the approach for disagreements. The Netherlands almost no procedures for co-operative compliance. The main focus of the Netherlands is professional judgement. Disagreement between parties is solved in court. For legal proceedings the existing legal framework existing without co-operative compliance is applicable.

Legal structures should fit the society they are applicable. With this consideration, there might be an approach optimal and an approach suboptimal. The UK approach fits its general legal environment and assuming the legal environment is fitting the society the approach is societal sufficient. This is also the situation for the Netherlands, even though the Dutch variant creates no legal security itself. The conclusion on which approach creates legal security is obvious: only the approach of the United Kingdom is creating legal security.

From a societal perspective additional insight is created on the functioning of law. To consider the societal perspective consider a group of taxpayers which is covered in both co-operative compliance regimes: multinational companies. Multinational companies must comply with laws and regulations applicable in every country they operate. It is likely that a company has operations in both the UK and the Netherlands as both countries are located near each other.

To illustrate the situation a fictional company is used: FAHR. The UK profits of FAHR are taxable in the UK. The Dutch profits of FAHR are taxable in the Netherlands. FAHR has no operations in other countries and is therefore not able to avoid taxation. FAHR is willing to 
participate in both the UK and Dutch co-operative compliance regime as the corporate governance of the company is aimed at complying with good tax behaviour. Before implementing a tax compliant risk management framework FAHR has considered both the UK and Dutch guidance. In such a situation a remarkable situation occurs. The Dutch documentation creates the possibility of professional judgement. The UK documentation on the other side creates limited possibility for professional judgement and FAHR must comply with the specific guidance from the HMRC.

So, what would happen in practice if FAHR must comply with both the UK and Dutch compliance policy? FAHR implements the UK co-operative compliance framework as this has detailed structures. In addition, it considers whether the implemented internal tax control environment requires additions based on professional judgement (Dutch requirement). As the UK approach is thoroughly documented there are probably very few additions. The situation that occurs is one where the UK co-operative compliance regime has been implemented. Implementing the UK co-operative compliance regime results in complying with both the UK and Dutch co-operative compliance approach.

The question is whether it is societal desirable that by following the UK co-operative compliance regime it is possible to comply with the Dutch co-operative compliance regime. To my opinion, it is desirable. The OECD initiative is aimed at international tax compliance which results ultimately in less tax expenses for both the taxpayer and tax administration. Considering the purpose of the OECD's co-operative compliance initiative this purpose is fulfilled by the combination of the UK and Dutch co-operative compliance approach. FAHR is not required to implement two separate tax control frameworks. In addition, as FAHR is willing to comply with tax regulations, the tax administration's resources can be applied on other companies. Although, this is especially the situation in the UK. The Dutch tax inspectors are still allowed to audit the taxes of FAHR as this is part of the Dutch co-operative compliance policy. The situation might occurs that the UK tax authority decides not to audit the taxes, while the Dutch tax authority decides it will. As both tax authorities are both responsible for the operations in its own territory, this is not an essential shortcoming from the societal perspective.

To conclude, the UK and Dutch co-operative compliance approach differs essentially. Although both approaches fit in their own legal environment, the UK approach creates much more certainty for taxpayers, not in the last place because it is creating legal security. To my opinion, the UK co-operative compliance approach is better, however, from an international perspective undesirable. The UK approach is better in guiding companies. The UK approach creates legal security which is essential for companies. However, if all countries decide to create their own framework, international operating companies must comply with many co-operative compliance regimes which creates a huge tax administration. Monitoring changes in cooperative compliance regimes takes a lot of time. So, the UK co-operative compliance approach is excellent as long as the international co-operative compliance approaches are comparable with the Dutch co-operative compliance approach.

\section{CONCLUSION}

This paper proved the difference of co-operative compliance between countries. Moreover, it gives insight in the possibility for co-operative compliance regimes. If several countries implement co-operative compliance approach comparable to the UK an administrational burden for internationalization is existing. This paper is the first scientific evidence that cooperative compliance requires an international approach instead of the national approaches currently applied. In addition, this research adds to the legal co-operative compliance framework that it proves the benefits of the framework. This paper proved that the framework 
can be applied in comparing different co-operative compliance approaches. Further research can focus on comparing other countries by applying the co-operative compliance framework applied in this research.

\section{References}

[1]. Colon, D.W. \& Swagerman, D.M, Enhanced Relationship Participation Incentives for (Dutch) Multinational Organizations, 2015, Accounting \& Taxation, 7 (1), 93-101.

[2]. Colon, D.W. and D.M. Swagerman, Enhanced relationship preparedness in a Dutch multinational context: A tax control framework, 2015, Journal of Accounting and Taxation, 7 (1), 13-18.

[3]. Colon, D.W. Legal security differences: co-operative compliance in the Netherlands. International journal of advanced engineering and management research, 2017, 2(1), 97-106.

[4]. Colon, D.W. Legal Security: Co-Operative Compliance in The United Kingdom. Journal of Research in Business and Management, 2017, 4(11), 66-69.

[5]. Ibid 3

[6]. Ibid 4

[7]. Al-Najjar, B., The Effect of Governance Mechanisms on Small and Medium-Sized Enterprise Cash Holdings: Evidence from the United Kingdom. Journal of Small Business Management, 2015. 53(2): p. 303-320.

[8]. Leylad, P., The Constitution of the United Kingdom: a contextual analysis. $3^{\text {rd }}$ edition ed2016, London: Hart Publishing (United Kingdom).

[9]. Harrison, K. and N. Ryder, The Law Relating to Financial Crime in the United Kingdom. $2^{\text {nd }}$ edition ed2016, London: Routledge (United Kingdom).

[10]. Seer, R. and A. Wilms, Surcharges and Penalties in Tax Law. $1^{\text {st }}$ edition ed2016, Amsterdam: IBFD (the Netherlands).

[11]. Pattaro, E. and C. Roversi, Legal Philosophy in the Twentieth Century: The Civil Law World. $12^{\text {th }}$ edition ed2016, Dordrecht: Springer (the Netherlands). 